\title{
MISSIONARY WOMEN AS EDUCATORS: THE CMS SCHOOLS IN NEW ZEALAND, 1823-1835
}

\author{
Tanya Fitzgerald
}

Much of the literature on the early period of British colonization of New Zealand has assumed that missionary men participated in the public world of work while their wives participated in the private world of the home. As women have been seen as occupying the domestic sphere of the home, historians have further viewed their work as relatively unimportant. Across this literature it is also usually assumed that-probably because men were engaged in the 'public sphere'-it was the missionary men who were responsible for providing education.

This paper concentrates on the activities of two early missionary women, Marianne Williams and her sister-in-law, Jane Williams. There is concrete evidence to suggest that these women were sent to New Zealand as part of the first wave of missionary women to 'civilize' Maori by converting them to Christianity. As women and educators, Marianne and Jane played critical roles in the success of the mission and, as will be argued, their presence in the mission station permitted missionary men to undertake their duties.

\section{CMS Policy on Women as Missionaries}

The Church Missionary Society was established in England in April 1799. One of the initial Resolutions adopted by the newly formed Society was to

List of Abbreviations

AIM Auckland Institute and Museum Library

AU The University of Auckland

CMS Church Missionary Society

NZJH New Zealand Journal of History 
'endeavour to propagate the knowledge of the Gospel among the Heathen.' The purpose of the Society was to bring the knowledge of the Gospel to 'heathen' and it was through the schools that this knowledge was to be disseminated, not the pulpit.

In the eighteenth century the broad purpose of the CMS was to send Anglican missionaries to 'Africa and the rest of the heathen world.' Initially this organization was called 'The Society for Missions to Africa and the East' but by 1812 the title had been modified to 'The Church Missionary Society for Africa and the East.' In the space of little more than a decade, then, West Africa, Australia, and New Zealand became the focus of attention for the CMS missionary endeavour. ${ }^{2}$ The Sierra Leone Mission was renamed in 1814 to 'The Christian Institution of Sierra Leone established and supported by the British Church Missionary Society for the Maintenance and Education of African Children and for the diffusion of Christianity and of Useful Knowledge among the Natives. 3

Not only had the CMS turned its attention to its African and Australasian Missions but its purpose was, as indicated by the title of the Sierra Leone mission, explicitly educative. As early as November 1799 the CMS had made it quite clear that the primary aim of the African mission was to educate the native children 'so as to be missionaries to their countrymen. ${ }^{4}$ In practice, this meant that these children were to be educated according to missionary policy, and that the new forms of knowledge they acquired through missionary education would then be diffused to their families and communities through them. The importance of the mission school was further stated by the CMS:

A grant of land having been made to the Society by the Colonial Government and the Society having requested a large addition to this grant the way is prepared for the establishment adapted to carry these plans into realisation. Here a schoolhouse should be erected on the National Plan for 1200 to 1500 children with a Church or Chapel for Public Worship and suitable accommodation for the children.

The instructions clearly outlined the need for a school to be established before a church was built. The CMS saw too the need to 'accommodate' its pupils-that is, to take the African children away from their families and communities in order

1. Cited in E. Stock, The History of the Church Missionary Society: Its Environment, its Men and its Work (London: Church Missionary Society, 1899), 1: 68.

2. J.R. Elder, ed., Marsden's Lieutenants (Dunedin: Coulls Somerville Wilkie, 1934), 15.

3. CMS Committee Minutes, 14 Nov. 1814, Committee Minutes 1799-1884, MC Microfilm, AU. The italics here represent underlinings in the manuscripts.

4. 4 Nov. 1799, Committee Minutes 1799-1884, MC Microfilm, AU.

5. 14 Nov. 1814, Committee Minutes $1799-1884$, MC Microfilm, AU. 
to be able to teach them. Presumably the children 'needed' to be away from the influence of their families.

This was the policy framework which underpinned the first CMS mission to New Zealand in 1814 as well as those stations that followed. The education of Maori children was perceived by the CMS as a means of conducting 'the glorious work of civilising, and by God's blessing, evangelizing New Zealand,' by which missionaries would transform New Zealand in 'comparatively a little time' into 'an English nation.' ${ }^{6}$ Education was thus the vehicle through which the civilizing and Christianizing process would be achieved. Through regular schooling the missionaries were to transform Maori society and to recreate 'the pleasantries of a Christian society."7

The importance of education in mission work has not been made clear in much of the New Zealand literature. ${ }^{8}$ Yet it is clear that the CMS intended the major missionary purpose to be educative: to teach their religious beliefs and practices in schools with the intention of changing the society they had come to convert. The schoolroom, not the pulpit, was the central site in which this was conducted.

Reading the New Zealand mission material against this policy indicates that local CMS mission stations placed the same emphasis on education as the parent body. In a letter to the Secretary of the Society, John Butler outlined the progress he had made in establishing a mission station at Kiddeekiddee (Kerikeri). Butler wrote that he had built a dwelling for himself, a house for his 'working natives,' a place for his potatoes to be stored and his fowls and goats, and a schoolhouse, and that 'I feel very anxious about a place for Public worship, but how or when a Church will be built, it is hard to say." 9 Similarly in 1824 William Hall wrote that he had built a schoolroom 'convenient to Mr King's dwelling house' and that a chapel was his next concern. ${ }^{10}$ In the CMS station at least, the schoolroom was of primary importance and preceded the building of a church. Initially the CMS established stations at Rangihoua (1814) and Kerikeri (1819). Stations at Paihia (1823) and Waimate (1831) were established when the missionaries considered 'the situation of the Natives in the neighbourhood is exceedingly

6. John Butler to Secretary of Sydney Correspondence Committee, 6 Nov. 1814, Mission Books 1820-1822, CN/M1 Microfilm, AU.

7. Instructions to Early Missionaries, 1821, Pamphlet Collection, BX8328, AIM.

8. See for example M.P.K. Sorrenson, 'How to Civilise Savages; Some Answers from Nineteeth Century New Zealand,' NZJH 9, 2 (1975): 97-110; J. Binney, 'Christianity and the Maoris to 1840; a comment,' NZJH 3, 2 (1969): 143-65. Both writers argue that the missionary purpose was to civilize and Christianize Maori but do not make it clear how this process was implemented.

9. John Butler to Secretary Pratt, 10 Oct. 1821, Mission Books 1820-1822, CN/M1 Microfilm, AU.

10. William Hall Journal, 2 Oct. 1824, Mission Books 1824-1826, CN/M3, Microfilm, AU. 
favourable to the regular communication of instruction., ${ }^{11}$ Thus new mission stations were built to provide schooling for surrounding Maori communities. Educational 'need,' not religious need, dictated the presence of a mission station in a particular area.

This material indicator of the importance of education to the missions was reflected in the instructions given to CMS missionaries prior to their departure for New Zealand:

The ultimate object of the Society in forming such an establishment would be the introduction of the Gospel among the New Zealanders. The settlers....would therefore be expected to form a small Christian society, living together in habits of industry, piety, and love. Whatever time could be gained from the manual labour necessary for the support of the settlement and the instruction of the natives in the arts practised by the settlers, must be conscientiously devoted, as schoolmasters and catechists, to the religious care of the youth, and through them to the enlightening and instruction of the natives themselves. ${ }^{12}$

Similar instructions were repeated to individual mission couples. Henry and Marianne Williams, for example, were sent to New Zealand to provide for 'the Christian education of young New Zealanders, perhaps of both sexes,' and to 'bring the noble but benighted race of New Zealanders into the enjoyment of the light and freedom of the Gospel. ${ }^{13}$ In these instructions the CMS quite pointedly stated that 'the business of the school is the permanent hope of the mission,' indicating that the role of teacher was central to the success of the mission. ${ }^{14}$ Within these instructions Marianne was further directed to take responsibility for 'the education of female children, and in the general improvement of the condition of women in New Zealand.' To this the CMS added:

We doubt not but Mrs Williams, next to the care of your own children, will readily contribute all that may be in her power; and we have the best hope that you will exhibit to the Natives, the instructive example of a happy Christian family. ${ }^{15}$

11. Henry Williams, Report to Special Committee Meeting held at Paihia, 6 Jan. 1835, Minutes of Australasia Mission 1834-1839, CN/04c, Microfilm, AU.

12. Elder, Marsden's Lieutenants, 20.

13. Ibid.

14. Ibid.

15. Instructions to Henry Williams, 6 Aug. 1822, Henry Williams. Letters and Papers 1783-1844, Series B, No 1, C MS335, typescript, AIM. 
There can be no doubt that Marianne was sent to New Zealand as a missionary teacher, and that her assigned tasks were to teach 'female children' and to interact with Maori women. Marianne was not sent to accompany Henry solely as 'his wife' but, as Henry himself stated, as a 'fellow helper,' a fellow missionary. ${ }^{16}$ Even within the official histories of the CMS the role of women as missionaries is quite clearly stated:

Each sister should remember that being a missionary, she shares those rights which are common to all missionaries, having a commission as clear, a responsibility as great, and a connexion as direct with the Parent Committee, through the local governing body, as have any of the male missionaries of the Society. But being a woman as well as a missionary, each sister has assigned to her...a distinct limit of service and a definite sphere...she goes forth to evangelize and instruct. ${ }^{17}$

Not only was there a specific agenda to teach, but it was the women missionaries who were assigned to this task. This policy was applicable to the New Zealand mission. Both Henry and Marianne Williams were directed to ensure that education took place in the Bay of Islands, but it was Marianne who was given specific responsibility in this area. One obvious reason for this directive was her prior experience as a teacher. CMS women from stations established in the Bay of Islands in the 1820 s - women such as Marianne Williams, her sister-in-law, Jane Williams, and Sarah Fairburn - had taught in Girls Schools and Sunday Schools prior to their departure for New Zealand.

Their teaching background was not, however, the only reason these women were selected by the CMS as missionaries and nominated as teachers for the Bay of Islands. The CMS regarded teaching as a moral rather than an economic activity. As the instructions to Marianne Williams indicated, missionary women were to reinforce the model of a pious and virtuous woman. As teachers, missionary women were responsible for re-shaping Maori girls and women in this direction in order to re-create the "pleasantries of a Christian society., 18

The teaching activities of the CMS women were directed at Maori women and girls as 'the general improvement of the condition of women in New Zealand' was a clearly stated aim of the mission from its inception. This priority, and the role of missionary women in meeting it, was implemented once this wave of missionaries reached the Bay of Islands.

16. Ibid.

17. Cited in G.Gollock, Missionaries at Work (London: Church Missionary Society, 1898), 131.

18. Instructions to Early Missionaries, 1821, Pamphlet Collection, BX8328, AIM. 


\section{Women as Missionary Educators}

Marianne and Henry Williams arrived in the Bay of Islands in September 1823. Once dwellings were established and a source of food supply negotiated with local Maori, missionaries turned their attention to their main task of education. The specific instructions Marianne had been issued with were to 'improve the condition' of Maori women and to provide education 'perhaps for both sexes.' The 'condition' of Maori women and girls was 'far more degraded than that of the males,' so their education was seen as most urgent. ${ }^{19}$

In April 1824 the first school opened - for 'native girls.' In order to be able to attend the school, Maori women and girls had to cut their hair, wash and dress in appropriate (European) attire, and stay within the 'picket fences' of the mission. ${ }^{20}$ This attempt to educate Maori women and girls by keeping them within the confines of the mission station was intended to serve four related purposes.

First, the CMS women believed that keeping Maori women and girls confined to the geographic boundaries of the station would prevent them from 'going to the shipping. ${ }^{21}$ It was the presumed and actual sexual activity that Maori women were involved in that had been pinpointed by the missionaries as rendering women and girls the most 'degraded' and hence most in 'need' of education. Hence this specific condition of permanent residence at the mission station sought to locate Maori women and girls under the watchful eye of missionary women and thus minimize the possibility of them visiting ships when they arrived.

Second, in the schoolroom, the CMS women could instruct Maori women and girls in "everything of which we are capable of teaching them. ${ }^{22}$ Schooling was not conducted as a singular activity which children attended daily. Instead it required Macri women and girls to live permanently within the mission station. By this means missionary women sought to encourage Maori to adopt Christian values and practices and to reject Maori ways. According to missionary women the immediate benefits of the schoolroom and its associated practices were to

19. Henry Williams, 17 July 1826 , Henry Williams and Marianne Williams, William Williams and Jane Williams. Letters and Papers, Series B, Vol F, MS335, typescript, AIM.

20. S.Goldsbury, 'Behind the Picket Fence: The Lives of Missionary Wives in Pre-Colonial New Zealand' (Unpublished M.A. thesis, University of Auckland, 1986).

21. Henry Williams, Journal, 6 Nov. 1826, Henry Williams and Marianne Williams, William Williams and Jane Williams. Letters and Papers, Series B, Vol F, MS335, typescript, AIM.

22. Henry Williams, 1 Apr. 1826, Henry Williams and Marianne Williams, William Williams and Jane Williams. Letters and Papers, Series B, Vol G, MS335, typescript, AIM. 
present Maori women with a viable (moral) alternative to them visiting the 'shipping.' The long-term advantage was, of course, civilization.

Third, in providing a place for Maori to live whilst they attended the school, CMS women effectively took Maori away from the influence of their whanau (family) and kainga (village). The transformation of Maori from a savage and heathen being was premised on the notion that in order to become Christian and civilized, Maori had to learn and act in Pakeha ways. Central to this was to become a 'happy Christian family,' which could only be achieved within the family home itself. The Williams of Paihia were to provide the 'instructive example of a happy Christian family,' a model which Maori were to identify and attempt to recreate. ${ }^{23}$

The final reason for requiring Maori to reside with the missionaries was more explicitly political. If Maori children were present in the mission station then the missionaries were reasonably safe from invasion from neighbouring tribes. As John Butler wrote in 1819, 'they will be hostages for our security and their Tribes will be led to deal with us more kindly. ${ }^{24}$ However, the missionaries did not consider the girls to be suitable hostages. Sons of chiefs acted as hostages while the daughters of chiefs were the domestic servants of the missionary women. Nonetheless, the presence of girls and women with rank within the mission stations undoubtedly did offer the missionaries this type of protection - even if missionaries themselves were unaware of it!

The language missionary women used to delineate these educational activities drew on the language of England. More specifically they saw themselves as 'boarding' the 'New Zealand young ladies' at the school. Through this, however, missionary women attempted to change the way in which Maori thought, acted, and lived. ${ }^{25}$ In keeping Maori women and girls away from their families, the missionaries thought it possible to convert and educate these women. In providing an example of the pious Christian family it was hoped that when the women returned to their families these 'much improved and improving' women would then change their own families. ${ }^{26}$ Thus the nature of Maori society itself was to be transformed via the educative role of the missionary women, and through Maori women co-operating with this.

23. Instructions to Henry Williams, 6 Aug. 1822, Henry Williams and Marianne Williams, William Williams and Jane Williams. Letters and Papers, Series B, Vol F, MS335, typescript, AIM.

24. John Butler to Secretary, 8 Nov. 1819, Mission Books 1820-1822, CN/M1, Microfilm, AU.

25. Marianne Williams, Journal, 10 July 1826, Henry Williams and Marianne Williams, William Williams and Jane Williams. Letters and Papers, Series B, Vol F, MS335, typescript, AIM.

26. Marianne Williams, Oct. 1828, Henry Williams and Marianne Williams, William Williams and Jane Williams. Letters and Papers, Series B, Vol F, MS335, typescript, AIM. 
It was intended that Maori women and girls would become

useful in washing, ironing, sewing and nursing and begin to write and read with tolerable ease; these acquirements afford us much pleasure, but we are more gratified at perceiving that they become more orderly and obedient, and that their habits are more decorous and less dirty, though there remains very much to be reformed outwardly. ${ }^{27}$

This provides some clear clues as to the type of knowledge, skills, and attitudes that missionary women taught. These were to be achieved by Maori women and girls occupying the schoolroom from 9:00 to 12:00 each day, followed by them learning the 'principal domestic concerns' within the mission houses during the afternoon. ${ }^{28}$ The CMS women attempted to impose a degree of 'order' on Maori women and girls by regulating their day with a bell, by requiring them to dress in identical (European) attire, and go about their school work and 'manual labour' in an orderly, submissive, and obedient manner. Their skills in print literacy were not directed towards them becoming print literate so much as they were towards them acquiring Christian morality by reading the Bible.

This skill and moral-based educational agenda became more apparent once other forms of schooling were established. Maori and Pakeha, male and female, were taught different skills to equip themselves with their intended future occupations. Maori girls were taught to be 'good' domestics, that is, the servants of the missionary women. Pakeha girls were taught to be 'good' future wives and mothers, which involved (amongst other things) learning how to 'superintend' their Maori domestics. Maori boys were taught basic agricultural and carpentry skills. Pakeha boys were given the 'advantage of going to England' to be apprenticed to a surgeon. ${ }^{29}$

The role of missionary women as teachers remained central once these other avenues of formal education were established. They continued to be responsible for educating Maori girls, and undertook all the teaching of the Pakeha girls. Of these various modes of schooling, missionary men were responsible only for teaching Maori boys agricultural and carpentry skills. By 1828 when it became

27. Jane Williams to Lydia, 27 Mar. 1828, Henry Williams. Letters and Papers, 1783-1844, Series A, MS335, AIM.

28. Henry Williams, 12 July 1826 , Henry Williams and Marianne Williams, William Williams and Jane Williams. Letters and Papers, Series B, Vol F, MS335, typescript, AIM. See also William Williams, 28 Apr. 1828, Henry Williams and Marianne Williams, William Williams and Jane Williams. Letters and Papers, Series B, Vol F, MS335, typescript, AIM.

29. Henry Williams, 28 Feb. 1831, Henry Williams and Marianne Williams, William Williams and Jane Williams. Letters and Papers, Series B, Vol F, MS335, typescript, AIM. 
apparent that the CMS were not prepared to fund the travel to England for the Pakeha boys, teachers for these boys were sent from England. ${ }^{30}$ It is apparent however that it was the missionary women who played not only an important role, but the central role, in implementing the most fundamental task of the mission stations.

\section{Missionary Women as Wives}

In order to be appointed as a missionary in the first instance, men who applied to the CMS to be sent to its mission stations in Africa, Australia, and New Zealand were required to have useful skills such as carpentry, building, and twinemaking, and to be able to read and write. Men such as William Hall and John King who offered themselves as candidates were required by the CMS to attend lessons to increase their literacy. ${ }^{31}$ This is not surprising given the educative function of the missions. Nor is it surprising that men who were married to women with teaching backgrounds were more readily accepted as missionaries.

While women teachers lent strength to their husband's applications, those men who did not have wives were urged to marry by the CMS before leaving England for New Zealand. More specifically, such men were urged to marry 'suitable women,' who would not only be able to offer valuable labour support on the station, but would 'assist...in guarding the missionaries against the dangers of their situation. 32

The dangers the CMS were referring to were presumably related to the male (and stronger) sexual drive which, unless regulated by missionary women, offered a potentially disnuptive element within a well-ordered evangelical society. The necessity of having a wife to 'control' her husband's morality was a clear concern for William Yate, who journeyed from New Zealand to New South Wales a number of times to find a 'suitable' wife. Similarly, on the death of a wife, missionary men frequently re-married a short time later. ${ }^{33}$ Women, it seems, were seen as the necessary guardians of both the private and public virtues of their men.

30. Henry Williams, 20 Sept. 1831, in The Early Journals of Henry Williams; Senior Missionary in New Zealand of the Church Missionary Society 1826-1840, ed. L.M. Rogers (Christchurch: Pegasus Press, 1961).

31. CMS Committee Resolution, 6 Mar. 1809, Committee Minutes 1799-1884, MC Microfilm, AU; Samuel Marsden to Church Missionary Society, 3 Apr. 1809, Committee Minutes 1799-1884, MC Microfilm, AU.

32. 21 Dec. 1804, Committee Minutes 1799-1884, MC Microfilm, AU.

33. See Goldsbury, 'Behind the Picket Fence,' Appendix I. 
Women also provided vital productive and reproductive labour-labour which was crucial both to the missionary family and the mission station. Missionary women were engaged in the tasks of teaching, running the household, and caring for the sick. Men attended the Quarterly meetings, wrote official reports to the Society in London, apportioned finance, travelled the country, and learnt the language to 'declare to the Natives the glad tidings of Salvation. ${ }^{34}$ (That much of their time was taken up travelling and preaching lends further support to the argument that education was the central purpose of female missionary activity.)

Women such as Marianne and Jane Williams whose husbands were absent frequently and for sustained periods of time were essential to the survival of the mission. In the absence of their husbands, these women ran their households and the mission itself, negotiated with traders, and dealt with local Maori who entered the confines of the mission station. In order to be able to travel, men depended on the labour of their wives to run the day-to-day affairs of the mission. In other words, men could not have fulfilled their missionary duties without the labour of missionary women.

Although the domestic tasks performed by the women were difficult given the prevailing conditions, these household tasks were secondary to their real purpose for being in New Zealand. As Marianne commented in 1826, 'so many necessary things [are left] undone' as her role as teacher was more important than that of wife and mother. ${ }^{35}$

\section{Conclusion}

The historical literature on the CMS in New Zealand states that women accompanied their husbands as their wives, and that it was their task to run the household, rear the children, and supervise the servants. ${ }^{36}$ A closer reading of missionary society policy, and the evidence left by missionary women and men themselves, clearly indicate, however, that women accompanied their husbands as missionaries. As missionary women they had specific tasks and their presence in the mission was critical to the 'success' of the mission in several different ways.

The CMS were reluctant to send men to their missions unless they were accompanied by a wife. Indeed it was only on the very rare occasion that men

34. Instructions to Henry Williams, 6 Aug. 1822, Henry Williams and Marianne Williams, William Williams and Jane Williams. Letters and Papers, Series B, Vol F, MS335, typescript, AIM.

35. Marianne Williams, 2 Dec. 1826, Henry Williams and Marianne Williams, William Williams and Jane Williams. Letters and Papers, Series B, Vol F, MS335, typescript, AIM.

36. See Goldsbury, 'Behind the Picket Fence,' 12-14. 
were able to become, or remain, missionaries unless women were present. The presence of women enabled men to carry out their evangelical tasks. Further, men were dependent on the labour of their wives as it enabled men to work outside of the mission station. The central concern of the missionary women was education, and their central functions were to teach, improve, and reform 'the condition of [indigenous] women. ${ }^{37}$

37. Instructions to Henry Williams, 6 Aug. 1822, Henry Williams and Marianne Williams, William Williams and Jane Williams. Letters and Papers, Series B, Vol F, MS335, typescript, AIM. 